\title{
Hubungan Kepatuhan Pengobatan Dengan Kadar Gula Darah Sewaktu Pada Pasien Diabetes Melitus Tipe II
}

\author{
Muhammad Sahlan Zamaa dan Sainudin \\ Departemen Keperawatan Medikal Bedah / Program Studi Ilmu Keperawatan SekolahTinggi \\ Ilmu Kesehatan Makassar \\ E-mail: sahlan_nersuh@yahoo.com
}

\begin{abstract}
ABSTRAK
Berdasarkan data World Health Organization (WHO), diprediksi adanya peningkatan jumlah penyandang DM yang menjadi salah satu ancaman kesehatan global. Jumlah penderita DM kian meroket tiap tahunnya, baik di indonesia maupun dunia. Tercatat di data WHO memprediksi kenaikan jumlah penyandang DM di Indonesia dari 8,4 juta di tahun 2000 menjadi sekitar 21,3 juta pada tahun 2030. Penelitian ini bertujuan untuk mengetahui hubungan kepatuhan berobat dengan kadar gula darah sewaktu pada pasien diabetes melitus tipe II di Poli Interna RSUD Labuang Baji Makassar.Jenis penelitian ini adalah penelitian observasional analitik dengan pendekatan Cross Sectional study yang merupakan rancangan penelitian dengan melakukan pengukuran atau pengamatan pada saat yang bersamaan (sekali waktu). Teknik pengambilan sampel pada penelitian ini dilakukan dengan metode accidental Sampling, sebanyak 54 responden dan instrumen penelitiannya menggunakan kuesioner.Hasil penelitian dianalisis mengunakan uji Chi - Square diperoleh nilaip 0,00 $(\rho<\alpha)$. Hal ini menunjukkan bahwa ada hubungan kepatuhan berobat dengan kadar gula darah sewaktu pada pasien diabetes melitus tipe II.Simpulan dari penelitian ini yaitu ada hubungan yang signifikan antarakepatuhan berobat dengan kadar gula darah sewaktu pada pasien diabetes melitus tipe II di Poli Interna RSUD Labuang Baji Makassar. Disarankan kepada penderita DM untuk selalu mematuhi proses pengobatan agar kadar GDS tetap stabil.
\end{abstract}

Kata Kunci : Diabetes Melitus Tipe 2, Gula Darah Sewaktu, Kepatuhan Berobat,

\begin{abstract}
World Health Organization (WHO) predicts an increase in the number of people with diabetes mellitus who become one of global health threats. The number of diabetes mellitus patients raises each year worldwide. Moreover, WHO estimates an increase in the number of people with diabetes mellitus in Indonesia from 8,4 million in 2000 to about 21,3 million by 2030 . This study aimed to recognize the relationships of treatment compliance with blood glucose level on patients with diabetes mellitus type II in poliinternaLabuangBaji Hospital. This was analytic observational research with cross sectional study design with the number of sample was 54 patients selected by accidental sampling. Data collection applied questionnaires. The result of chi-square test revealed $\mathrm{p}$ value $0,00(\mathrm{p}<\alpha)$ indicated that there was a relationship of treatment compliance with blood glucose levels on patients with diabetes mellitus type II. It concluded that there were correlation of treatment compliance with blood glucose levels on patients with diabetes mellitus type II. It is encouraged to diabetes mellitus patients to regularly adhere to the treatment process to keep blood glucose levels stable.
\end{abstract}

Keywords: Treatment Compliance, Blood Glucose Levels, Diabetes Mellitus Type II

\section{PENDAHULUAN}

Dunia modern pada zaman saat ini, memicu terjadinya perubahan gaya hidup pada masyarakat di dalamnya. Salah satu perubahan gaya hidup dan pola hidup adalah dengan mengkonsumsi makanan yang tidak sehat yang banyak mempengaruhi kadar gula darah seperti makanan cepat saji, minum-minuman bersoda dan jenis makanan yang lainnya. Hal ini menjadi salah satu faktor pemicu peningkatan terjadinya penyakit degeneratif dalam hal ini seperti penyakit diabetes melitus. Diabetes melitus adalah penyakit kronis progresif yang ditandai dengan ketidakmampuan tubuh untuk melakukan metabolisme karbohidrat, lemak dan protein, mengarah ke 
hiperglikemia (kadar glukosa darah tinggi) (Black, J.M dan Hawks, J.H. 2014).

Saat ini penelitian epidemologi menunjukkan adanya kecenderungan peningkatan angka insidensi dan prevalensi DM tipe 2 di berbagai penjuru dunia. DM tipe 2, sebelumnya disebut NIDDM atau diabetes melitus onsetdewasa, adalah gangguan yang melibatkan, baik genetik dan faktor lingkungan. DM tipe 2 adalah tipe DM paling umum, mengenai $90 \%$ orang yang memiliki penyakit. DM tipe 2 , biasanya terdiagnosis setelah usia 40 tahun dan lebih umum diantara dewasa tua, dewasa obesitas, dan etnik serta populasi ras tertentu. Namun diagnosis DM tipe 2 pada anak-anak dan remaja meningkat, terutama pada Amerika-Afrika dan Amerika Hispanik/Latin (Black, J.M dan Hawks, J.H. 2014).

World Health Organization(WHO), memprediksi adanya peningkatan jumlah penyandang DM yang menjadi salah satu ancaman kesehatan global. Jumlah penderita DM kian meroket tiap tahunnya, baik di indonesia maupun dunia. Tercatat di data WHO memprediksi kenaikan jumlah penyandang DM di Indonesia dari 8,4 juta di tahun 2000 menjadi sekitar 21,3 juta pada tahun 2030 (PERKENI, 2015). Senada dengan WHO, International Diabetes Federation (IDF) Atlas 2015, memprediksi untuk usia 20-79 tahun jumlah penderita diabetes di Indonesia dari 10 juta pada tahun 2015 menjadi 16,2 juta pada tahun 2040. Dengan angka tersebut Indonesia menempati urutan ke-6 di dunia pada tahun 2040, atau naik satu peringkat dibanding data IDF pada tahun 2015 yang menempati peringkat ke-7 di dunia (IDF, 2015).
Laporan hasil Riset Kesehatan Dasar (Riskesdas), menunjukkan terjadinya peningkatan prevalensi DM di Indonesia dari 5,7\% tahun 2007 menjadi 6,9\% atau sekitar 9,1 juta pada tahun 2013. Diabetes telah menjadi penyebab kematian terbesar ke-4 di dunia. Di tahun 2012 sudah ada 4,8 juta kematian yang disebabkan langsung oleh diabetes. Tiap 10 detik ada satu orang atau tiap 1 menit ada 6 orang yang meninggal akibat penyakit yang berkaitan dengan diabetes (Tandra, H., 2013).Data Sample Registration Survey tahun 2014 menunjukkan bahwa diabetes merupakan penyebab kematian terbesar nomor 3 di Indonesia dengan presentase sebesar $(6,7 \%)$, setelah stroke $(21,1 \%)$ dan penyakit jantung koroner $(12,9)$ (Kemkes, 2016).

Sedangkan berdasarkan data Survailans penyakit tidak menular Bidang P2PL Dinas Kesehatan Provinsi Sulawesi Selatan tahun 2014, terdapat 27.470 kasus penyakit diabetes melitus dengan 747 kematian. Sedangkan berdasrkan data Dinas Kesehatan Kota Makassar pada tahun 2015, penyakit DM menempati peringkat empat dari sepuluh penyebab utama kematian di Kota Makassar yaitu sebanyak 191 kasus dengan jumlah penderita sebanyak 25.145 jiwa (Dinas Kesehatan Kota Makassar, 2015).

RSUD Labuang Baji Makassar, jumlah pasien rawat jalan pada tahun 2014 sebanyak 209 pasien, tahun 2015 sebanyak 277 pasien, dan pada tahun 2016 sebanyak 195 pasien yang menderita penyakit diabetes melitus (Rekam Medik RSUD Labuang Baji Makassar).

Diperkirakan masih banyak (sekitar $50 \%$ ) penyandang diabetes yang belum terdiagnosis di Indonesia. Selain itu hanya 
dua pertiga saja dari yang terdiagnosis yang menjalani pengobatan, baik non farmakologis maupun farmakologis. Dari yang menjalani pengobatan tersebut hanya sepertiganya saja yang terkendali dengan baik. Bukti-bukti menunjukkan bahwa komplikasi diabetes dapat dicegah dengan kontrol glikemik yang optimal, namun demikian di Indonesia sendiri target pencapaian kontrol glikemik masih belum tercapai secara memuaskan, yang sebagian besar masih di atas target yang diinginkan sebesar 7\% (PERKENI, 2015).

Kemajuan kedokteran memungkinkan pasien diabetes melitus hidup lebih lama dengan kualitas hidup lebih baik bila pasien tersebut memantau kadar gula darahnya dengan cermat, menggunakan data-data ini untuk melakukan perubahan farmakologi serta gaya hidupnya, dan menggunakan sistem pemberian insulin yang baru, seperti pompa insulin subkutan. Di samping itu, obat-obat yang kini tersedia akan meningkatkan metabolisme glukosa dan sensitivitas insulin tubuh sendiri untuk mencapai kontrol glikemia yang optimal serta mencegah progresivitas penyakitnya agar tidak terjadi komplikasi jangka panjang ( Kowalak, J.P., dkk. 2014).

Berdasarkan penelitian yang dilakukan oleh Nurlaili Haida Kurnia Putri dan Muhammad Atoillah Isfandiari pada tahun 2013, dengan judul "Hubungan empat pilar pengendalian DM tipe 2 dengan rerata kadar gula darah" dari keempat pilar pengendalian DM tipe 2 tersebut salah satu yang diteliti oleh peneliti adalah "kepatuhan berobat". Dari keseluruhan responden sebanyak 53 responden sebagian besar responden tidak patuh melakukan pengobatan, yaitu sebesar $28(52,8 \%)$ responden. Sedangkan responden yang patuh melakukan berobat sebesar 25 (47,2\%). Distribusi ini berdasarkan kepatuhan pengobatan yang dilakukan responden. Hasil penelitian ini tentang tabulasi silang kepatuhan berobat yang diketahui bahwa sebagian besar responden dengan kepatuhan berobat yang baik memiliki rerata kadar gula darah < $160 \mathrm{mg} / \mathrm{dl}$ yaitu sebanyak 41,5\%. Sebagian besar responden yang tidak patuh melakukan berobat memiliki rerata kadar gula $\geq 160 \mathrm{mg} / \mathrm{dl}$ yaitu sebanyak $26,4 \%$. Berdasarkan uji statistik dengan Uji Chi Square didapatkan $\rho=0,003(\rho<\alpha)$, yang berarti penelitian ini ada hubungan antara kepatuhan berobat dengan rerata kadar gula darah acak(Putri, N.H.K., Dan Isfandiari, M.A., 2013).

Penelitian yang dilakukan oleh Norma Risnasari pada tahun 2014 ada hubungan tingkat kepatuhan diet pasien diabetes melitus dengan munculnya komplikasi. Kemudian dilanjutkan nilai keeratan hubungan yaitu dengan perhitungan koefisiensi kontingensi didapatkan hasil 0,011 yang artinya sangat rendah yaitu semakin tidak patuh semakin tinggi kemungkinan terjadinya komplikasi (Risnasari, N., 2014).

Berdasarkan latar belakang diatas, kadar gula darah penderita diabetes melitus tipe II diperkirakan dapat dikendalikan apabila penderita diabetes melitus patuh dalam menjalani berobat. Oleh karena itu, peneliti tertarik untuk melakukan penelitian tentang hubungan kepatuhan berobat dengan kadar gula darah sewaktupada pasien diabetes melitus tipe II di Poli Interna RSUD Labuang Baji Makassar. 


\section{METODE}

Berdasarkan rumusan masalah dan tujuan penelitian maka jenis penelitian ini adalah penelitian observasional analitikdengan pendekatan cross sectional. cross sectional merupakan rancangan penelitian dengan melakukan pengukuran atau pengamatan pada saat bersamaan (sekali waktu) antara faktor risiko/paparan dengan penyakit.

\section{HASIL}

Penelitian ini dilaksanakan di Poli Interna RSUD Labuang Baji Makassarpada tanggal 20 Februari - 23 Maret 2018.Penelitian ini menggunakan desain penelitian cross sectional study dengan teknikaccidental sampling berjumlah 54 responden penderita DM tipe II yang berumur 36-76 tahun, penelitian ini bertujuan untuk mengetahui hubungan antara variabel independen dengan variabel dependen.

Hasil penelitian didapatkan melalui pembagian kuesioner dan wawancara yang kemudian diisi oleh responden sesuai dengan kemampuannya tanpa ada intervensi dari siapapun dan melihat kepatuhan berobat pasien selama pasien menjalani pengobatan.

Data yang diperoleh melalui tahapan editing, coding, dan tabulasi data. Selanjutnya, hasil penelitian akan disajikan dalam bentuk tabel distribusi frekuensi dan pesentase yang disertai penjelasan dari masing-masing tabel sebagai berikut :

\section{Karakteristik Responden}

Tebel 1 Karakteristik Penderita Diabetes Melitus Tipe II

\begin{tabular}{lcc}
\hline Variabel & N & \% \\
\hline Umur (Tahun) & & \\
$36-45$ & 4 & 7,4 \\
$46-55$ & 17 & 31,5 \\
$56-65$ & 29 & 53,7 \\
$>65$ & 4 & 7,4 \\
\hline Jenis kelamin & & \\
Laki-laki & 13 & 24,1 \\
Perempuan & 41 & 75,9 \\
\hline Lama Menderita & & \\
DM & 22 & 40,7 \\
$<5$ Tahun & 32 & 59,3 \\
$\geq 5$ Tahun & & \\
\hline Jumlah & 54 & 100 \\
\hline
\end{tabular}

Analisis Univariat

Tabel 2 Distribusi Responden Berdasarkan Kepatuhan Berobat

\begin{tabular}{ccc}
\hline $\begin{array}{c}\text { Kepatuhan } \\
\text { berobat }\end{array}$ & $\mathbf{N}$ & $\boldsymbol{\%}$ \\
\hline Tidak patuh & 29 & 53,7 \\
Patuh & 25 & 46,3 \\
\hline Jumlah & 54 & 100 \\
\hline
\end{tabular}

Tabel 3 Distribusi Responden Berdasarkan Kadar Gula Darah Sewaktu

\begin{tabular}{ccc}
\hline $\begin{array}{c}\text { Kadar Gula } \\
\text { Darah Sewaktu }\end{array}$ & N & \% \\
\hline Tinggi & 36 & 66,7 \\
Normal & 18 & 33,3 \\
\hline Jumlah & 54 & 100 \\
\hline
\end{tabular}

Analisis Bivariat

Tabel 4 Distribusi Responden Berdasarkan Kepatuhan Berobat

\begin{tabular}{ccc}
\hline $\begin{array}{c}\text { Kepatuhan } \\
\text { berobat }\end{array}$ & $\mathbf{N}$ & $\mathbf{\%}$ \\
\hline Tidak patuh & 29 & 53,7 \\
Patuh & 25 & 46,3 \\
\hline Jumlah & 54 & 100 \\
\hline
\end{tabular}


Tabel 5 Distribusi Responden Berdasarkan Kadar Gula Darah Sewaktu

\begin{tabular}{ccc}
\hline Kadar Gula Darah Sewaktu & N & \% \\
\hline Tinggi & 36 & 66,7 \\
Normal & 18 & 33,3 \\
\hline Jumlah & 54 & 100 \\
\hline
\end{tabular}

Tabel 6 Hubungan Kepatuhan Berobat

Dengan Kadar Gula Darah Sewaktu Pada Diabetes Melitus Tipe II

\begin{tabular}{|c|c|c|c|c|c|c|c|}
\hline \multirow{3}{*}{$\begin{array}{l}\text { Kepatuha } \\
\text { n Berobat }\end{array}$} & \multicolumn{4}{|c|}{ Kadar Gula Darah Sewaktu } & \multirow{2}{*}{\multicolumn{2}{|c|}{ Jumlah }} & \multirow{2}{*}{$\begin{array}{c}p- \\
\text { value }\end{array}$} \\
\hline & \multicolumn{2}{|c|}{ Tinggi } & \multicolumn{2}{|c|}{ Normal } & & & \\
\hline & $\mathbf{N}$ & $\%$ & $\mathbf{N}$ & $\%$ & $\mathbf{n}$ & $\%$ & \multirow{4}{*}{0,00} \\
\hline $\begin{array}{l}\text { Tidak } \\
\text { Patuh }\end{array}$ & 29 & 100 & 0 & 0 & 29 & 100 & \\
\hline Patuh & 7 & 28 & 18 & 72 & 25 & 100 & \\
\hline Jumlah & 36 & 66,7 & 18 & 33,3 & 54 & 100 & \\
\hline
\end{tabular}

\section{PEMBAHASAN}

Berdasarkan tabel 5, setelah dilakukan uji chi-square diperoleh nilai pvalue $=0,00$ dengan tingkat kemaknaan $\alpha$ $=0,05$. Hal ini menunjukkan bahwa hipotesis diterima dimana nilai $p<\alpha$ yang artinya ada hubungan yang signifikan antara kepatuhan berobat dengan kadar gula darah sewaktu pada pasien diabetes melitus tipe II di Poli Interna RSUD Labuang Baji Makassar.

Penelitian ini sejalan dengan penelitian yang dilakukan oleh Nurlaili Haida Kurnia Putri dan Muhammad Atoillah Isfandiari (2013) , Hasil penelitian ini tentang tabulasi silang kepatuhan berobat yang diketahui bahwa sebagian besar responden dengan kepatuhan berobat yang baik memiliki rerata kadar gula darah $<160 \mathrm{mg} / \mathrm{dl}$ yaitu sebanyak $41,5 \%$. Sebagian besar responden yang tidak patuh melakukan pengobatan memiliki rerata kadar gula $\geq$ $160 \mathrm{mg} / \mathrm{dl}$ yaitu sebanyak 26,4\%. Berdasarkan uji statistik dengan Uji Chi
Square didapatkan $\rho=0,003(\rho<\alpha)$, yang berarti penelitian ini ada hubungan antara kepatuhan berobat dengan rerata kadar gula darah acak.

Kepatuhan adalah perilaku individu (misalnya : minum obat, mematuhi diet, atau melakukan perubahan gaya hidup) sesuai anjuran terapi dan kesehatan. Tingkat kepatuhan dapat dimulai dari tindak mengindahkan setiap aspek anjuran hingga mematuhi rencana.

Pada penelitian ini ditemukan pasien yang patuh berobat namun kadar gula darahnya tinggi sebanyak 7 responden $(28,0 \%)$. Hal ini disebabkan karena pasien hanya patuh berobat namun tidak mematuhi diet dan melakukan perubahan gaya hidup sehat. Kepatuhan perawatan diabetes melitus dalam hal ini penderita harus melaksanakan program perawatan diabetes melitus seperti melakukan hidup sehat, melakukan pengobatan secara rutin, aturan berobat yang ditetapkan, mengikuti jadwal pemeriksaan dan rekomendasi hasil penyelidikan (Darmawan, R., 2013).

Selain itu, juga ditemukan pasien diabetes melitus tipe II yang tidak patuh 
berobat sebanyak29 responden (100\%), dan dari 29 responden (100\%) tersebut semua memiliki kadar gula darah sewaktu tinggi. Hal ini sesuai dengan apa yang dikatakan oleh PERKENI 2015, bahwa memang masih sangat banyak pasien diabetes melitus tipe II yang tidak patuh dalam menjalani pengobatan, baik non farmakologis maupun farmakologis. Dari yang menjalani pengobatan tersebut hanya sepertiganya saja yang terkendali dengan baik. Bukti-bukti menunjukkan bahwa komplikasi diabetes dapat dicegah dengan kontrol glikemik yang optimal, namun demikian di Indonesia sendiri target pencapaian kontrol glikemik masih belum tercapai secara memuaskan, yang sebagian besar masih di atas target yang diinginkan sebesar $7 \%$.

Ada beberapa hal yang dapat mempengaruhi kepatuhan seseorang diantaranya faktor pemungkin (Enabling Factors). Yang dimaksud dengan faktor pemungkin adalah sarana dan prasarana atau fasilitas untuk terjadinya perilaku kesehatan, misalnya puskesmas, posyandu, rumah sakit, makanan bergizi. Sebuah keluarga yang sudah tahu masalah kesehatan mengupayakan keluarganya untuk melakukan kontrol gula darah. Tetapi apabila keluarga tersebut tidak mampu mengadakan fasilitas itu semua karena jarak yang terlalu jauh, maka dengan terpaksa kontrol yang dijadwalkan tidak dapat dilakukan.

Kemajuan kedokteran saat ini sebenarnya memungkinkan pasien diabetes melitus hidup lebih lama dengan kualitas hidup lebih baik bila pasien tersebut memantau kadar gula darahnya dengan cermat, menggunakan data-data ini untuk melakukan perubahan farmakologi serta gaya hidupnya, dan menggunakan sistem pemberian insulin yang baru, seperti pompa insulin subkutan. Di samping itu, obat-obat yang kini tersedia akan meningkatkan metabolisme glukosa dan sensitivitas insulin tubuh sendiri untuk mencapai kontrol glikemia yang optimal serta mencegah progresivitas penyakitnya agar tidak terjadi komplikasi jangka panjang ( Kowalak, J.P., dkk. 2014).

\section{SIMPULAN}

Ada hubungan yang signifikan antara kepatuhan berobat dengan kadar gula darah sewaktu pada pasien diabetes melitus tipe II di Poli Interna RSUD Labuang Baji Makassar ( $p: 0,00)$.

Masyarakat khususnya pasien DM tipe II juga perlu diberikan pemahaman akan pentingnya patuh dalam berobat untuk menstabilkan kadar gula darah agar dapat menekan komplikasi yang akan terjadi, sehingga masyarakat patuh terhadap anjuran yang diberikan oleh tenaga kesehatan dalam kehidupan sehari-hari.

\section{DAFTAR PUSTAKA}

Black, J.M. dan Hawks, J.H. 2014. Keperawatan Medikal Bedah : Manajemen Klinis Untuk Hasil Yang Diharapkan. Edisi 8 Buku 2. Elsevier. Singapore

Damayanti, S. 2015. Diabetes Mellitus \& Penatalaksanaan Keperawatan. Nuha Medika. Yogyakarta

Darmawan, R. 2013. Kepatuhan Penderita DM.

http://nursecaremine.blogspot.co. id/2013/05/kepatuhan-penderitadm.html. Diakses Pada Tanggal 18 November 2017

Fredy, F.C. 2017. Gula Darah-FungsiKelainan (Kerjanya). http://www.kerjanya.net/faq/5323 
-gula-darah.html. Diakses Pada Tanggal 19 September 2017

Gustina, Suratun, Heryati . 2014. "FaktorFaktor Yang Berhubungan Dengan Kepatuhan Diet Diabetes Mellitus Pada Pasien DM ( Factors Associated With Compliance Diet Of Diabetes Mellitus ). jurnal keperawatan" 2 (3): 97-107.

Haskas, Y. 2017. Determinan Perilaku Pengendalian Diabetes Melitus Diwilayah Kota Makassar. Jurnal Departemen keperawatan. Vol 1. Sekolah Tinggi Ilmu Kesehatan NANI Hasanuddin Makassar.

Hidayat, A. Aziz Alimul. 2017. Metodologi Penelitian Keperawatan Dan Kesehatan. Salemba Medika. Jakarta

IDF. 2015.IDF Diabetes Atlas. International Diabetes Federation. Jurnal International Diabetes Federation doi:10.1289/image.ehp.v119.i03.

Japerson, H. 2013. Memahami Apa Itu Gula Darah. https://www.deherba.com/memah ami-apa-itu-kadar-gula-

darah.htmlDiakses Pada Tanggal 19 September 2017

Kemkes. 2016. Mari Kita Cegah Diabetes Dengan Cerdik. http://www.depkes.go.id. Diakses Pada Tanggal 13 September 2017

Kowalak, J.P., dkk. 2014. Buku Ajar Patofisiologi (Professional Guide to Pathophysiology). Penerbit Buku Kedokteran EGC. Jakarta

Maghfuri, A. 2016. Buku Pintar Perawatan Luka Diabetes Melitus. Salemba Medika. Jakarta Maryunani, A. 2013. Diabetes Pada Kehamilan " Edisi Kedua”. CV.Trans Info Media. Jakarta Timur
Notoatmodjo, S. 2010. Pendidikan Dan Perilaku Kesehatan. Rineka Cipta. Jakarta

Nurarif, AH dan Kusuma, H. 2015. Aplikasi Asuhan Keperawatan Berdasarkan Diagnosa Medis Dan NANDA NIC-NOC. Mediaction. Yogyakarta

Nurlaili Haida Kunia Putri dan Muhammad Atoillah Isfandiari. 2013. "Hubungan Empat Pilar Pengendalian Dm Tipe 2 Dengan Rerata Kadar Gula Darah." Jurnal Berkala Epidemiologi 1 (2): 23443.

Pawenrusi, E.P., dkk. 2017. Pedoman Penulisan Skripsi Edisi 14. cetakan ketigabelas. Sekolah Tinggi Ilmu Kesehatan Makassar : Makassar

Perkeni. 2015.Konsensus Pengelolaan Dan Pencegahan Diabetes Melitus Tipe 2 Di Indonesia 2015.Pengurus Besar Perkumpulan Endokrinologi Indonesia (PB Perkeni). Jurnal Kensus. Vol. 1. doi:10.1017/CBO9781107415324 .004

$\begin{array}{ll}\text { Putri, } & \text { F.D. 2016.Teori }\end{array}$

Kepatuhan.(online).http://digilib. uinsby.ac.id/13045/3/Bab\%202.p $d f$. Diakses Pada Tanggal 22 September 2017

Risnasari, Norma. 2014. "Hubungan Tingkat Kepatuhan Diet Pasien Diabetes Mellitus Dengan Munculnya Komplikasi Di Puskesmas Pesantren II kota Kediri." Jurnal Nerma Risnasari 1 (25): 15-19.

Safitri, Inda Nofriani. 2013. "Kepatuhan Penderita Diabetes Mellitus Tipe II Ditinjau Dari Locus Of Control." Jurnal Ilmiah Psikologi Terapan1 (2): 273-290.

Suiraoka, IP. 2012. Penyakit Degeneratif (Mengenal, Mencegah dan 
Mengurangi Faktor Risiko 9

Penyakit Degeneratif). Nuha Medika. Yogyakarta

Tandra, H. 2013. Life Healthy With Diabetes (Diabetes Mengapa \& Bagaimana?). Rapha Puslishing. Yogyakarta 